\title{
Pregnancy and Lambing Rate Following Laparoscopic Artificial Insemination with Two Different Types of Diluent and Frozen-thawed Sperm Dose in Ewes
}

\section{Pankaj Kumar Jha ${ }^{1,2^{*}}$, M. Golam Shahi Alam ${ }^{1}$ and Farida Yeasmin Bari ${ }^{1}$}

${ }^{1}$ Department of Surgery and Obstetrics, Faculty of Veterinary Science, Bangladesh Agricultural University, Mymensingh-2202, Bangladesh; ${ }^{2}$ Nepal Agricultural Research Council (NARC), Khumaltar, Lalitpur, Kathmandu, P.O. Box. 1950, Nepal.

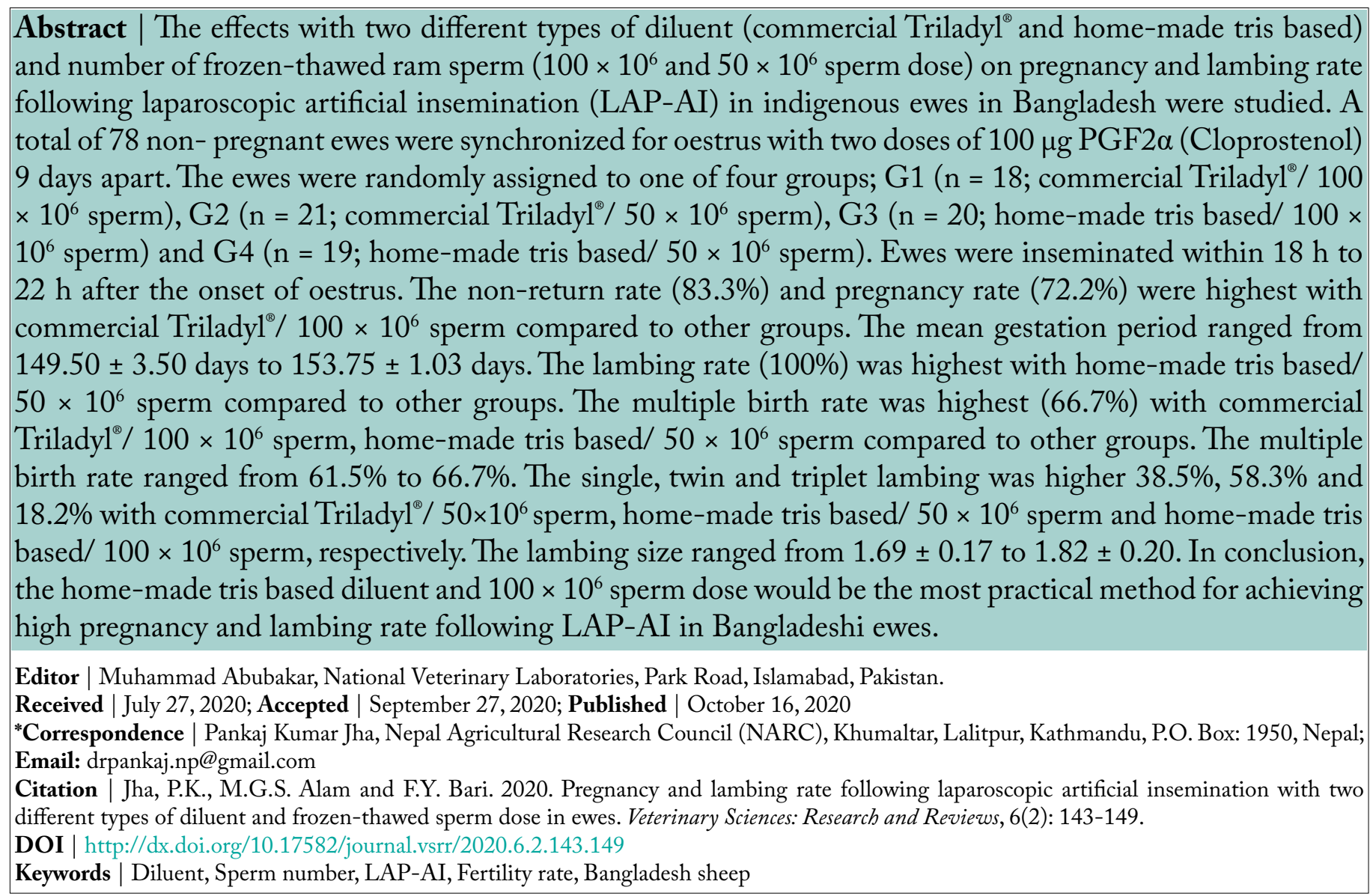

\section{Introduction}

Sheep farmers in Bangladesh are curiously Olooking for sustainable appropriate reproductive techniques. Frozen semen of superior ram and use of artificial insemination (AI) is commonly used worldwide to improve the sheep herd genetics through the selective breeding programs. Mainly two types of AI; transcervical (TC-AI) and laparoscopic (LAP-AI) are practiced in ewes. TC-AI using frozen semen is hardly practiced because of low pregnancy and lambing rates (Montoro et al., 2002). The LAP$\mathrm{AI}$ is the choice in ewes, results in an increased fertility rate by injecting semen directly into the uterine 
horn (Fair et al., 2005; Kumar and Naqvi, 2014). To establish LAP-AI in indigenous ewes in Bangladesh, different analogues and doses of prostaglandin are used to observe the effectiveness of oestrus response (Roy et al., 2014; Zohara et al., 2014), and pregnancy rate using frozen semen (Rekha et al., 2016). The pregnancy rate following LAP-AI with frozen ram semen in Bangladeshi ewes varied widely $47 \%$ to 60\% (Azizunnesa, 2016). The success of AI depends on the quality of semen, oestrus synchronization, types of insemination, the number of frozen-thawed sperm and timing of insemination (Montoro et al., 2002; Kumar and Naqvi, 2014). LAP-AI is superior to $\mathrm{TC}-\mathrm{AI}$ for pregnancy rate and requires a reduction in the number of spermatozoa per insemination. Different doses of frozen sperm $25 \times 10^{6}$ (Salamon and Maxwell, 2000; Khalifa et al., 2013), $100 \times 10^{6}$ (Padilha et al., 2012) and $250 \times 10^{6}$ (Anel et al., 2003) have been documented to use for LAP-AI in sheep. Despite the above described, different types of diluents and frozen-thawed sperm dose, the influence on fertility in indigenous ewes in Bangladesh remains to be established. Therefore, the present study was designed to compare two different types of diluent (commercial Triladyl $^{\oplus}$ and home-made tris based) and frozen-thawed sperm dose $\left(100 \times 10^{6}\right.$ and $50 \times$ $\left.10^{6}\right)$ on the pregnancy and lambing rate following LAP-AI in indigenous ewes.

\section{Materials and Methods}

All procedures were approved by the Animal Experimental Ethics Committee, Department of Surgery and Obstetrics, Bangladesh Agricultural University (AEEC/ DSO54 BAU/ 02/ 2015) and were carried out from November 2016 to December 2017.

\section{Animals}

Indigenous ram $(\mathrm{n}=10)$, best selected based on semen quality evaluation were used as semen donors. Indigenous ewes $(n=78)$, non-pregnant were selected with the aid of ultrasound scanning (DRAMINSKI ANIMAL profi portable ultrasound scanner, Poland) using a $5.0 \mathrm{MHz}$ transabdominal transducer. Both rams and ewes were belonged to a project funded by Bangladesh Academy of Science and United States Department of Agriculture (BAS-USDA; LS-02) and reared at Sheep Research Farm, DSO, BAU. Feeding, grazing, watering, and housing remained as routinely done in Sheep Research Farm, DOS, BAU (Jha et al., 2018).
Frozen semen production

All chemicals used in this study were from Sigma (St. Louis, MO, USA) and Merck (Darmstadt, Germany). Semen collection and evaluation was performed as described by Jha et al. (2018). Briefly, semen was collected using an artificial vagina and semen samples were evaluated at $35^{\circ} \mathrm{C}$. Sperm motility (\%; warming stage at $37^{\circ} \mathrm{C}$ ) was estimated subjectively by placing a drop of semen $5 \mu \mathrm{L}(100$ $x$ ) using a coverslip. Sperm concentration $\left(10^{6} / \mathrm{mL}\right)$ was calculated using a Neubauer counting chamber at a dilution of 1:200 (Semen: buffered formal saline, $200 \times$ ). Only ejaculates with volume $\geq 0.5 \mathrm{~mL}$, sperm motility $\geq 80 \%$, and sperm concentration $\geq 2500 \times$ $10^{6} / \mathrm{mL}$ were processed.

Two different types of diluent, commercial (Triladyl ${ }^{\circledR}$ ) and home-made tris based were selected based on ram semen freezing experiment (Jha et al., 2019). The semen sample was extended using a one-step and two-step protocol for commercial Triladyl ${ }^{\oplus}$ and home-made tris based, respectively. Individual ram semen ejaculates were extended to two different sperm concentration $400 \times 10^{6}$ and $200 \times 10^{6}$ spermatozoa/ $\mathrm{mL}$ to prepare final sperm dose $100 \times 10^{6}$ and $50 \times 10^{6}$ per $0.25 \mathrm{~mL}$ French mini straw.

The straws were frozen in liquid nitrogen (LN2) vapor in a Styrofoam box using 3 step freezing technique developed in the DSO laboratory, BAU (Jha et al., 2019). Finally, the straws were plunged into the LN2 $\left(-196^{\circ} \mathrm{C}\right)$.

The semen straws were thawed in warm water at 37 ${ }^{\circ} \mathrm{C}$ for $20 \mathrm{sec}$. Batches with sperm motility $\geq 50 \%$ were stored in Cryocan for LAP-AI purposes.

\section{Experimental design}

The ewes $(\mathrm{n}=78)$ were randomly allocated into 4 groups: G1 ( $\mathrm{n}=18$; commercial Triladyl ${ }^{\Phi} / 100 \times 10^{6}$ sperm), G2 $\left(\mathrm{n}=21\right.$; commercial Triladyl $150 \times 10^{6}$ sperm), G3 ( $\mathrm{n}=20$; home-made tris based/ $100 \times 10^{6}$ sperm) and G4 ( $\mathrm{n}=19$; home-made tris based/ $50 \times$ $10^{6}$ sperm). Ewes were inseminated within $18 \mathrm{~h}$ to 22 $h$ after the onset of oestrus.

\section{Oestrous synchronization}

Oestrous synchronization was done according to Zohara et al. (2014). All ewes were given two doses of $0.4 \mathrm{~mL}(100 \mu \mathrm{g})$ intramuscular (IM) prostaglandin F2 $\alpha$ (PGF2 $\alpha$ ) analogue (Cloprostenol, Ovuprost, 
Bayer New Zealand Ltd., Auckland, New Zealand) 9 days apart.

\section{Laparoscopic artificial insemination (LAP-AI)}

Selected oestrus ewes were withheld from feed and water for at least $12 \mathrm{~h}$. After proper clipping and shaving the lower abdominal region of the ewes, they were sedated with xylazine (Xylazin ${ }^{\circledR}$, Indian Immunological Ltd, Hydrabad, India) @ $0.22 \mathrm{mg} / \mathrm{kg}$ IM. Ewes were restrained in the laparoscopic cradle in dorsal recumbence with the rear legs lifted to an approximate $45^{\circ}$ angle. Each leg fortified by a rope with a cradle hook. The operating area was scrubbed with antiseptic solution $\left(7.5 \% \mathrm{w} / \mathrm{v}\right.$, Povisep ${ }^{\circledR}$, Jayson Pharmaceuticals Ltd, Dhaka, Bangladesh) and $4 \mathrm{ml}$ local anaesthetic lignocaine hydrochloride (Jasocaine ${ }^{\varpi}$, 2\%, Jayson Pharmaceuticals Ltd., Dhaka, Bangladesh) was injected $\mathrm{SC}$ on incision site; $5 \mathrm{~cm}$ to either side of the mid ventral line and $5 \mathrm{~cm}$ anterior to the mammary gland. Two small incisions $(0.3 \mathrm{~cm}$ to 0.4 $\mathrm{cm}$ ) was made through the skin to the left and right, approximately $3 \mathrm{~cm}$ to $4 \mathrm{~cm}$ of the midline and $4 \mathrm{~cm}$ to $5 \mathrm{~cm}$ cranial to the teats. Two trocars and cannulas, one ( $7 \mathrm{~mm}$ diameter $\times 150 \mathrm{~mm}$ length) and another (5 $\mathrm{mm}$ diameter $\times 100 \mathrm{~mm}$ length) were inserted into the peritoneal cavity through the left and right incision, respectively. The peritoneal cavity was inflated with $\mathrm{CO}_{2}$ (LAPARO CO 2 PNEU insufflator, 2232, Richard Wolf, Germany). The trocars were removed from each cannula. A laparoscope tube $\left(7 \mathrm{~mm}, 180^{\circ}\right)$ fitted to a high-intensity fibre optic light source (Endolight led light sources, 4215, Richard Wolf Germany) was introduced into $7 \mathrm{~mm}$ cannula. With the help of laparoscopic tube and right-hand cannula, the reproductive tract was manipulated gently to position of the uterine horn for insemination. The loaded LAPAI pipette (Robertsone pipette standard for LAP-AI in sheep with tube, Minitube, Slovakia) was introduced into right-hand cannula. One uterine horn (approx. $3 \mathrm{~cm}$ to $4 \mathrm{~cm}$ cranial to the cornual bifurcation) was punctured by the needle attached with the LAP-AI pipette. The semen, half of the $0.25 \mathrm{ml}$ French semen straw, was directly injected intra-luminally of the uterine horn. The procedure was repeated on the other uterine horn. After insemination, the pipette, laparoscope tube and both cannula was removed. Excess gas if any was expressed and a sulphanilamide powder (Sumid-Vet ${ }^{\oplus}$, Square Pharmaceuticals Ltd., Bangladesh) was applied at the wound sites. The skin wound was closed with silk 2-0 (non-absorbable) using interrupted suture. The sutured site was painted with Povisep ${ }^{\oplus}$ and applied a tincture benzoin cotton seal. Surgical instruments were drenched with povidone iodine solution $(7.5 \% \mathrm{w} / \mathrm{v}$, Povisep ${ }^{\circledR}$, Jonson Pharma Ltd., Bangladesh), water and finally wiped with ethylene alcohol between LAP-AI of ewes.

\section{Reproductive performance}

The onset of oestrous was determined by monitoring every $6 \mathrm{~h}$ for $30 \mathrm{~min}$ to $40 \mathrm{~min}$ from $12 \mathrm{~h}$ to $96 \mathrm{~h}$ following the second PGF2 $\alpha$ treatment, with the help of a mature ram wearing an apron. The nonreturn of oestrus was monitored 13 days to 21 days after insemination. The non-returned ewes were checked for pregnancy by ultrasound 40 days to 50 days after AI (Olivera-Muzante et al., 2011). The oestrus response (number of ewes showing oestrus/ number treated $\times 100$ ), non-return rate (number of ewes not returning to oestrus/ number inseminated $\times 100$ ), pregnancy rate (number of pregnant ewes/ number inseminated $\times 100$ ), lambing rate (number of lambing ewes/ number of pregnant ewes $\times 100$ ), multiple birth rate (number of ewes lambing twin or triplet/ total number of lambing ewes $\times 100$ ), lambing size (number of total lambs/ number of lambing ewes $\times 100$ ) and the female or male lamb rate (number of female or male lamb/ total number of lambs $\times 100$ ) were recorded (Turk et al., 2008).

\section{Data analysis}

Excel (Microsoft Excel 2010) was used to record and calculate the frequency distribution of onset of oestrus, and SPSS (Version 20; IBM) was used for other data analysis. The gestation periods and lambing size were compared by one-way analysis of variance (ANOVA) followed by post hoc Tukey-HSD test. The other reproductive traits were compared by Chi-squared test. Data for gestation period and lambing size were presented as mean \pm SEM and a value $p<0.05$ was considered significantly different.

\section{Results and Discussion}

Non-return rate, pregnancy rate and gestation period The non-return, pregnancy rate and gestation period are presented in Table 1 . The non-return rate (83.3\%) and pregnancy rate $(72.2 \%)$ were highest with commercial Triladyl ${ }^{\oplus} /$ sperm dose $100 \times 10^{6}$ compared to other groups. However, the non-return rate and pregnancy rate ranged from $73.7 \%$ to $83.3 \%$ and $63.2 \%$ to $72.2 \%$, respectively. The mean gestation period ranged from $149.50 \pm 3.50$ to $153.75 \pm 1.03$ days. 
Table 1: Effects of different types of diluent and frozen sperm dose on reproductive performance in erves following $L A P-A I$.

\begin{tabular}{|c|c|c|c|c|c|c|}
\hline \multirow{3}{*}{\multicolumn{2}{|c|}{ Reproductive parameters }} & \multicolumn{4}{|c|}{ Groups } & \multirow[b]{3}{*}{ P-value } \\
\hline & & \multicolumn{2}{|c|}{ Commercial triladyl $^{\oplus}$} & \multicolumn{2}{|c|}{ Home-made tris based } & \\
\hline & & $100 \times 10^{6}$ sperm dose & $50 \times 10^{6}$ sperm dose & $100 \times 10^{6}$ sperm dose & $50 \times 10^{6}$ sperm dose & \\
\hline Ewes (n) & & 18 & 21 & 20 & 19 & \\
\hline Non-return rate (\%) & & $83.3(15 / 18)$ & $81.0(17 / 21)$ & $80.0(16 / 20)$ & $73.7(14 / 19)$ & 0.930 \\
\hline Pregnancy rate (\%) & & $72.2(13 / 18)$ & $71.4(15 / 21)$ & $65.0(13 / 20)$ & $63.2(12 / 19)$ & 0.908 \\
\hline \multirow{3}{*}{$\begin{array}{l}\text { Gestation period } \\
\text { (days) }(\text { mean } \pm \text { SEM })\end{array}$} & Single & $153.0 \pm 0.40$ & $151.4 \pm 1.88$ & $152.25 \pm 1.03$ & $153.75 \pm 1.03$ & \\
\hline & Twin & $153.16 \pm 0.74$ & $152.85 \pm 0.70$ & $152.4 \pm 1.32$ & $153.0 \pm 0.65$ & \\
\hline & Triplet & $151.0 \pm 3.0$ & 156.0 & $149.50 \pm 3.50$ & 152.0 & \\
\hline \multicolumn{2}{|l|}{ Lambing rate (\%) } & $92.3(12 / 13)$ & $86.7(13 / 15)$ & $84.6(11 / 13)$ & $100(12 / 12)$ & 0.749 \\
\hline \multicolumn{2}{|l|}{ Multiple birth rate (\%) } & $66.7(8 / 12)$ & $61.5(8 / 13)$ & $63.6(7 / 11)$ & $66.7(8 / 12)$ & 1.000 \\
\hline \multirow[t]{3}{*}{ Fecundity (\%) } & Single & $33.3(4 / 12)$ & $38.5(5 / 13)$ & $36.4(4 / 11)$ & $33.3(4 / 12)$ & \multirow[t]{3}{*}{0.993} \\
\hline & Twin & $50.0(6 / 12)$ & $53.8(7 / 13)$ & $45.5(5 / 11)$ & $58.3(7 / 12)$ & \\
\hline & Triplet & $16.7(2 / 12)$ & $7.7(1 / 13)$ & $18.2(2 / 11)$ & $8.3(1 / 12)$ & \\
\hline \multicolumn{2}{|c|}{ Lambing size $($ mean \pm SEM $)$} & $1.82 \pm 0.20$ & $1.69 \pm 0.17$ & $1.81 \pm 0.22$ & $1.75 \pm 0.17$ & \\
\hline \multicolumn{2}{|c|}{ Female lamb rate $(\%)$} & $45.5(10 / 12)$ & $59.9(13 / 22)$ & $60.0(12 / 20)$ & $38.1(8 / 21)$ & \multirow[t]{2}{*}{0.409} \\
\hline \multicolumn{2}{|l|}{ Male lamb rate (\%) } & $54.5(12 / 22)$ & $40.9(9 / 22)$ & $40.0(8 / 20)$ & $61.9(13 / 21)$ & \\
\hline
\end{tabular}

\section{Lambing performance}

The lambing rate (100\%) was highest with homemade tris based/ sperm dose $50 \times 10^{6}$ compared to other groups. However, the lambing rate was ranged from $84.6 \%$ to $100 \%$ (Table 1). The multiple birth rate was highest $(66.7 \%)$ with commercial Trilady ${ }^{\oplus} /$ sperm dose $100 \times 10^{6}$, home-made tris based/ sperm dose $50 \times 10^{6}$ compared to other groups. However, the multiple birth rate ranged from $61.5 \%$ to $66.7 \%$. The single, twin and triplet lambing was higher 38.5\%, $58.3 \%$ and $18.2 \%$ with commercial Triladyl / sperm dose $50 \times 10^{6}$, home-made tris based/ sperm dose 50 $\times 10^{6}$ and home-made tris based/ sperm dose $100 \times$ $10^{6}$, respectively. The lambing size ranged from $1.69 \pm$ 0.17 to $1.82 \pm 0.20$.

LAP-AI is the method of choice for AI with frozen semen in sheep. Following LAP-AI, the pregnancy rate is comparable to natural service or fresh semen. The diluent home-made tris based and sperm dose $100 \times 10^{6}$ can be recommended for sustainable LAP$\mathrm{AI}$ in indigenous sheep in Bangladesh.

The success of AI depends on quality of frozen semen and timing of AI (Hashemi et al., 2006). The nonreturn rate was in agreement with Olafsson (1980) and Langford et al. (1979) who reported little difference in non-return rate after 25 days but Olafsson used unsynchronized ewes whilst Langford et al.(1979)used synchronized ewes. The non-return rate is associated with too early insemination; deleterious effects often occurred both before and after maternal recognition of pregnancy (Olivera-Muzante et al., 2011).

The pregnancy rate (63.2\% to $72.2 \%)$ was higher than Azizunnesa (2016) who reported pregnancy rate $47 \%$ to $60 \%$ using frozen semen in Bangladeshi ewes. This apparent difference may be due to semen quality and sperm dose and ease performance of the technique. The pregnancy rate was comparable with Moses et al. (1997) who reported 62.9\%. The pregnancy rate was comparable with other authors who reported $60 \%$ to $66.6 \%$ using frozen sperm dose ranged from $30 \times 10^{6}$ to $100 \times 10^{6}$ per ewe (Fukui et al., 2007, 2008, 2010). Nevertheless, it is higher than $45.0 \%$ as described by Anel et al. (2005) after AI with $250 \times 10^{6}$ frozen sperm per ewe. The variation in experimental designs among studies might be responsible for the disparity in results of fertility trials (Petrie and Watson, 2006). The pregnancy rate may vary with quality of frozen semen and nature of oestrus. Khalifa et al. (2013) reported pregnancy rate $46.2 \%$ and $71.0 \%$ with frozen sperm dose $100 \times 10^{6}$ which was produced after using AndroMed and BioXcell diluent. This difference might be due to quality of number of motile sperms per dose insemination. A recent study by Eppleston et al. (1994) has shown a fertility rate of $40.3 \%$ with $16 \times 10^{6}$ motile spermatozoa and $72.8 \%$ with $64 \times$ 
$10^{6}$ motile spermatozoa. Evans and Maxwell (1987) found that $20 \times 10^{6}$ motile spermatozoa suffice for achieving a high pregnancy rate, while Eppleston et al. (1986) and Salamon et al. (1985) reported high fertility rate after insemination with $5 \times 10^{6}$ and 10 $\times 10^{6}$ motile spermatozoa, respectively. Findlater et al. (1991) reported similar results with $13 \times 10^{6}$ motile sperm cells per uterine horn. Factors such as age, parity, lactation status, and body condition of the ewe could influence fertility rate (Anel et al., 2005; Fukui et al., 2010; Palacin et al., 2012). The lambing rate $(84.6 \%$ to $100 \%)$ was higher than McKusick et al. (1998) who reported $75 \%$ following insemination with sperm dose $65 \times 10^{6}$. The lambing size $1.69 \pm$ 0.17 to $1.82 \pm 0.20$ was in agreement with McKusick et al. (1998) who reported lambing size $1.89 \pm 0.21$. The lambing rate, fecundity rate and lambing size depend upon various factors like; genetic potential, plane of nutritional and timing of AI (Downing and Scaramuzzi, 1991).

\section{Conclusions and Recommendations}

The diluent home-made tris based and sperm dose $100 \times 10^{6}$ would be the most practical method for achieving high pregnancy and lambing rate following LAP-AI in Bangladeshi ewes. This study provides some preliminary and important results and suggest for further research with a greater number of ewes.

\section{Acknowledgements}

This work was supported by Bangladesh Academy of Science and United States Department of Agriculture (BAS-USDA; LS-02). The authors are grateful to Md. Rafiqul Islam Talukder (PhD student) and Nazmun Naher (MS student) for assistance in LAP-AI.

\section{Author's Contribution}

This publication is part of Mr. Pankaj Kumar Jha $\mathrm{PhD}$ degree thesis supervised by Professor Farida Yeasmin Bari and Professor Md. Golam Shahi Alam. Pankaj Kumar Jha conceived the idea, designed, carried out the study and prepared the manuscript for publication, while Professor Farida Yeasmin Bari and Professor Md. Golam Shahi Alam supervised the study and proofread the manuscript for publication.

\section{Conflict of interest}

The authors have declared no conflict of interest.

\section{References}

Anel, L., Kaabi, M., Abroug, B., Alvarez, M., Anel, E., Boixo, J.C., de laFaente, L.F. and dePaz, P., 2005. Factors influencing the success of vaginal and laparoscopic artificial insemination in churra ewes: A field assay. Theriogenology, 63(4): 1235-1247. https://doi.org/10.1016/j. theriogenology.2004.07.001

Anel, L., De Paz, P., Alvarez, M., Chamorro, C.A., Boixo, J.C., Manso, A., Gonezalez, M., kaabi, M. and Anel, E., 2003. Field and in vitro assay of three methods for freezing ram semen. Theriogenology, 60(7): 12931308. https://doi.org/10.1016/S0093691X(03)00140-7

Azizunnesa, 2016. Preservation of indigenous ram semen. PhD thesis, Department of Surgery and Obstetrics, Bangladesh Agricultural University, Mymensingh-2202, Bangladesh.

Downing, J.A. and Scaramuzzi, R.J., 1991. Nutrient effects on ovulation rate, ovarian function and the secretion of gonadotrophic and metabolic hormones in sheep. J. Reprod. Fert., 43(209): 209-227.

Eppleston, J., Battye, K.M., Roberts, E.M. and Maxwell, W.M.C., 1986. Effect of thawed motility and intra-uterine dose of motile sperm on fertility in ewes. Proc. Austral. Soc. Reprod., Biologu, Australia. pp. 18-19.

Eppleston, J., Salamon, S., Moore, N.W. and Evans, G., 1994. The depth of cervical insemination and site of intrauterine insemination and their relationship to the fertility of frozenthawed ram semen. Anim. Reprod. Sci., 36(34): 211-225. https://doi.org/10.1016/03784320(94)90069-8

Evans, G. and Maxwell, W.M.C., 1987. Collection of semen, handling and examination of semen, dilution of semen, frozen storage of semen; Insemination. In: Salmon's artificial insemination of sheep and goats. Butterworths, Sydney. pp. 85-166.

Fair, S., Hanrahan, J.P., O’Meara, C.M., Duffy, P., Rizos, D., Wade, M., Donovan, A., Boland, M.P., Lonergan, P. and Evans, A.C.O., 2005. Differences between Belclare and Suffolk ewes in fertilization rate, embryo quality and accessory sperm number after cervical or laparoscopic artificial insemination. Theriogenology, 63(7): 1995-2005. 
theriogenology.2004.09.005

Findlater, R.C.F., Haresign, W., Curnock, R.M. and Beck, N.F.G., 1991. Evaluation of intrauterine insemination of sheep with frozen semen: effects of time of insemination and semen dose on conception rates. Anim. Sci., 53(1): 89-96. https://doi.org/10.1017/S0003356100006012

Fukui, Y., Kohno, H., Togari, T. and Hiwasa, M., 2007. Fertility of ewes inseminated intrauterinally with frozen semen using extender containing bovine serum albumin. J. Reprod. Dev., 53(4): 959-962. https://doi. org/10.1262/jrd.19017

Fukui, Y., Kohno, H., Togari, T., Hiwasa, M. and Okabe, K., 2008. Fertility after artificial insemination using a soybean-based semen extender in sheep. J. Reprod. Dev., 54(4): 286289. https://doi.org/10.1262/jrd.20004

Fukui, Y., Kohno, H., Okabe, K., Katsuki, S., Yoshizawa, M., Togari, T. and Watanabe, H., 2010. Factors affecting the fertility of ewes after intrauterine insemination with frozen-thawed semen during the non-breeding season. J. Reprod. Dev., 56(4): 460-466. https://doi. org/10.1262/jrd.10-015T

Hashemi, M., Safdarian, M. and Kafi, M., 2006. Estrous response to synchronization of oestrus using different progesterone treatments outside the natural breeding season in ewes. Small Ruminant Res., 65(3): 279-283. https://doi. org/10.1016/j.smallrumres.2005.07.051

Jha, P.K., Alam, M., Abdullah, A.M., Islam, T. and Bari, F., 2018. Selection of breeding rams by evaluating semen quality. J. Appl. Anim. Sci., 11(1): 9-20.

Jha, P.K., Alam, M.G.S., Mansur-AL, A., Naher, N., Islam, T., Bhuiyan, M.U. and Bari, F.Y., 2019. Cryopreservation of Bangladeshi ram semen using different diluents and manual freezing techniques. Cryobiology, 89: 35-41. https://doi.org/10.1016/j.cryobiol.2019.06.001

Khalifa, T., Lymberopoulos, A. and Theodosiadou, E., 2013. Association of soybean-based extenders with field fertility of stored ram (Ovis aries) semen: A randomized doubleblind parallel group design. Theriogenology, 79(3): 517-527. https://doi.org/10.1016/j. theriogenology.2012.11.009

Kumar, D. and Naqvi, S.M.K., 2014. Effect of time and depth of insemination on fertility of Bharat Merino sheep inseminated trans-cervical with frozen-thawed semen. J. Anim. Sci. Technol., 56(1): 1-6. https://doi.org/10.1186/20550391-56-8

Langford, G.A., Marcus, G.J., Hackett, A.J., Ainsworth, L., Peters, H.F. and Wolynetz, M.S., 1979. A comparison of fresh and frozen semen in the insemination of confined sheep. Can. J. Anim. Sci., 59(4): 685-691. https://doi. $\mathrm{org} / 10.4141 /$ cjas79-088

McKusick, B.C., Thomas, D.L., Gottfredson, R.G., Zelinsky, R.D. and Berger, Y.M., 1998. A comparison of transcervical and laparoscopic intrauterine artificial insemination techniques on reproductive performance of ewes. In proceedings: $46^{\text {th }}$ annual spooner sheep day. (Cooperative Extension of the University of Wisconsin-Extension: Madison, WI). pp. 32-9. Montoro, V., Gallego, R. and Pérez-Guzmán, M.D., 2002. Estado actual de los resultados de fertilidad en el esquema de selección de la raza ovina manchega. XXVII Jornadas Científicas y VI Jornadas Internacionales de la Sociedad Española de Ovinotecnia y Caprinotecnia. Valencia, Spain. pp. 1082-87.

Moses, D., Martinez, A.G., Iorio, G., Valcarcel, A., Ham, A., Pessi, H., Castanon, R., Macia, A. and Ade las Heras, A., 1997. A large-scale program in laparoscopic intrauterine insemination with frozen-thawed semen in Australian Merino sheep in Argentine Patagonia. Theriogenology, 48(4): 651-657. https://doi.org/10.1016/ S0093-691X(97)00281-1

Olafsson, T., 1980. Insemination of sheep with frozen semen. Results obtained in a field trial in Norway. Zuchthygiene, 15(2): 50-59. https:// doi.org/10.1111/j.1439-0531.1980.tb00489.x

Olivera-Muzante, J., Fierro, S., López, V. and Gil, J., 2011. Comparison of prostaglandinand progesterone-based protocols for timed artificial insemination in sheep. Theriogenology, 75(7): 1232-1238. https://doi.org/10.1016/j. theriogenology.2010.11.036

Padilha, R.T., Magalhães-Padilha, D.M., Cavalcante, M.M., Almeida, A.P., Haag, K.T., Gastal, M.O., Nunes, J.F., Rodrigues, A.P.R., Figueiredo, J.R. and Oliveira, M.A.L., 2012. Effect of insulin-like growth factor-I on some quality traits and fertility of cryopreserved ovine semen. Theriogenology, 78(4): 907-913. https:// doi.org/10.1016/j.theriogenology.2012.04.005

Palacin, I., Yaniz, J.L., Fantova, E., Blasco, M.E., 
Quintin-Casorran, F.J. and Sevilla-Mur, E., 2012. Factors affecting fertility after cervical insemination with cooled semen in meat sheep. Anim. Reprod. Sci., 132(3-4): 139-144. https:// doi.org/10.1016/j.anireprosci.2012.05.005

Petrie, A. and Watson, P., 2006. Statistics for veterinary and animal science. $2^{\text {nd }}$ ed. Oxford: Blackwell Publishing.

Rekha, A., Zohara, B.F., Bari, F.Y. and Alam, M.G.S., 2016. Comparison of commercial Triladyl extender with a tris-fructose-eggyolk extender on the quality of frozen semen and pregnancy rate after transcervical AI in Bangladeshi indigenous sheep (Ovis aries). Small Ruminant Res., 134:39-43. https:// doi.org/10.1016/j.smallrumres.2015.12.007

Roy, P.K., Zohara, B.F., Azizunnesa, A., Paul, A.K., Bhuiyan, M.M.U. and Bari, F.Y., 2014. Oestrus Synchronization with Ovuprost ${ }^{\oplus}$ and Prostenol ${ }^{\oplus}$ in the indigenous ewes of Bangladesh. J. Embryo Transfer, 29(2): 149-155. https://doi. org/10.12750/JET.2014.29.2.149

Salamon, S. and Maxwell, W.M.C., 2000. Storage of ram semen. Anim. Reprod. Sci., 62(13): 77-111. https://doi.org/10.1016/S03784320(00)00155-X

Salamon, S., Evans, G. and Maxwell, W.M.C. 1985. Fertility of ram semen frozen-stored for 16 years (sheep). In $17^{\text {th }}$ conference: Australian society for reproductive biology. Austral. Soc. Reprod. Biol. Adelaide, SA, Australia.

Türk, G., Gür, S., Sönmez, M., Bozkurt, T., Aksu, E.H. and Aksoy, H., 2008. Effect of exogenous $\mathrm{GnRH}$ at the time of artificial insemination on reproductive performance of Awassi ewes synchronized with progestagen-PMSG-PGF2 alpha combination. Reprod. Domest. Anim., 43(3): 308-313. https://doi.org/10.1111/ j.1439-0531.2007.00896.x

Zohara, B.F., Azizunnesa, Islam, M.F., Alam, M.G.S. and Bari, F.Y., 2014. Comparison of estrus synchronization by $\mathrm{PGF}_{2} \alpha$ and progestagen sponge with PMSG in indigenous ewes in Bangladesh. GSTF Int. J. Vet. Sci., 1(1): 27-37. https://doi.org/10.5176/23457880_1.1.4 